\title{
FAKTOR-FAKTOR YANG MEMPENGARUHI PARTISIPASI PETANI DALAM MENGEMBANGKAN BUDIDAYA KARET (Hevea brasiliensis, L) DI KECAMATAN KARANG BARU KABUPATEN ACEH TAMIANG
}

\author{
Hanisah $^{1} /$ Khaidir Gunawan $^{2}$ \\ ${ }^{1}$ Dosen Prodi Agribisnis Fakultas Pertanian \\ ${ }^{2}$ Alumni Prodi Agribisnis Fakultas Pertanian \\ UNIVERSITAS SAMUDRA
}

\section{RINGKASAN}

Faktor-Faktor Yang Mempengaruhi Partisipasi Petani Dalam Mengembangkan Budidaya Karet (Hevea brasiliensis, L) Di Kecamatan Karang Baru Kabupaten Aceh Tamiang. Tujuan penelitian adalah untuk mengetahui pengaruh harga, ketersediaan lahan dan produksi terhadap partisipasi petani dalam mengembangkan budidaya karet di Kecamatan Karang Baru Kabupaten Aceh Tamiang.

Penelitian ini dilaksanakan di Kecamatan Karang Baru Kabupaten Aceh Tamiang Provinsi Aceh. Objek penelitian ini adalah petani yang memiliki usahatani karet di Kecamatan Karang Baru Kabupaten Aceh Tamiang. Ruang lingkup penelitian ini terbatas pada harga, luas lahan dan produksi karet terhadap partisipasi petani di Kecamatan Karang Baru Kabupaten Aceh Tamiang.Hasil penelitian rata-rata umur petani sampel di desa sampel adalah 41 tahun, pendidikan 8 tahun, dan pengalaman sebesar 14 tahun. Rata-rata harga karet di desa sampel di Kecamatan Karang Baru sebesar Rp.6. 6.292/kg, rata-rata luas lahan karet di desa sampel di Kecamatan Karang Baru sebesar 1,35 hektar, sedangkan rata-rata produksi karet di desa sampel di Kecamatan Karang Baru sebesar 105 kg/minggu.

Rata-rata tingkat partisipasi petani karet di Kecamatan Karang Baru yaitu sebesar 2 (skor) artinya partisipasi petani karet dalam budidaya kurang sesuai anjuran. Hasil analisis regresi linear berganda diperoleh persamaan yaitu sebagai berikut: $Y=1,99+0,08 X_{1}+0,97 X_{2}-1,17 X_{3}$. Dari koefisien determinasi menunjukkan bahwa besar koefisien determinasi $\left(R^{2}\right)$ dihasilkan nilai $R^{2}=0,51$ atau $51 \%$. Hasil pengujian secara serempak diperoleh Fhitung $=12,63>F_{\text {tabel }}=$ 2,86 pada tingkat kepercayaan 95\% dan juga Fhitung $=12,63>$ Ftabel $=4,07$ pada tingkat kepercayaan 99\%, secara serempak variabel faktor tingkat harga, luas lahan, dan produksi memberi pengaruh yang sangat nyata terhadap partisipasi petani karet.

Hasil pengujian secara parsial pada variabel harga $\left(X_{1}\right)$ tingkat kepercayaan $95 \%$ dapat dilihat bahwa $\mathrm{t}_{1}$ cari $=11,76>\mathrm{t}$ tabel $=1,691$ dan $\mathrm{t}$ tabel $=2,440$ pada tingkat kepercayaan $99 \%$, ini berarti tingkat harga berpengaruh terhadap partisipasi petani usahatani karet di daerah penelitian. Hasil pengujian secara parsial pada variabel luas lahan $\left(X_{2}\right)$ tingkat kepercayaan $95 \%$ dapat dilihat bahwa t2 cari $=22,26>\mathrm{t}$ tabel $=1,691$ dan $\mathrm{t}$ table $=2,440$ pada tingkat kepercayaan $99 \%$, ini berarti tingkat luas lahan berpengaruh sangat nyata terhadap partisipasi petani usahatani karet di daerah penelitian. Hasil pengujian secara parsial pada variabel produksi $\left(\mathrm{X}_{3}\right)$ tingkat kepercayaan 95\% dapat dilihat bahwa $\mathrm{t} 3$ cari $=-54,72<\mathrm{t}$ tabel 1,691 dan pada tingkat kepercayaan 99\% bahwa t3 cari $=-54,72<\mathrm{t}$ tabel $=2,440$, ini berarti tingkat produksi sangat berpengaruh terhadap partisipasi petani usahatani karet di daerah penelitian.

Kata Kunci: Karet, Partisipasi, Harga, Luas Lahan, Produksi

\section{PENDAHULUAN}

\section{Latar Belakang}

Provinsi Aceh merupakan salah satu provinsi di Indonesia yang telah gencar dalam mengembangkan produksi karet. Ditinjau dari berbagai aspek, Kabupaten Aceh Tamiang sangat potensial untuk mengembangkan tanaman karet, baik ditinjau dari segi keadaan tanah, iklim, luas lahan dan penyediaan 
tenaga kerja maupun keadaan sosial ekonomi petani di daerah tersebut.

Kecamatan Karang Baru adalah salah satu kecamatan yang ada di Kabupaten Aceh Tamiang yang mengusahakan usahatani karet yang dijadikan sebagai sumber pendapatan tambahan bagi sejumlah petani di kecamatan tersebut. Partisipasi petani merupakan faktor yang penting dalam mengembangkan budidaya karet, dimana petani diikut sertakan dalam mengembangkan budidaya karet. Peranan petani sangatlah penting, tanpa partisipasi petani perkembangan budidaya karet tidak akan terlaksana. Partisipasi petani yang tinggi juga akan diikuti dengan perkembangan budidaya karet yang tinggi. Partisipasi adalah suatu wujud dari peran serta masyarakat dalam aktivitas berupa perencanaan dan pelaksanaan untuk mencapai tujuan pembangunan masyarakat (Sugiyah, 2010:2). Wujud dari partisipasi dapat berupa saran, jasa, ataupun dalam bentuk materi baik secara langsung maupun tidak langsung dalam suasana demokratis. Dalam masyarakat tani, partisipasi merupakan faktor yang penting dalam mengembangkan budidaya karet, dengan adanya saran yang membangun usaha tani karet maupun kegiatan-kegiatan suatu wujud dari peran serta petani karet, partisipasi petani dalam mengembangkan budidaya karet dalam penelitian ini meliputi sistem penanaman karet, pupuk yang digunakan, teknik dan frekuensi penyadapan yang dilakukan, cara pengendalian hama dan penyakit yang dilakukan pada usahatani karet, dan jenis klon karet yang Bapak/lbu gunakan pada usahatani karet. Harga karet sangat mempengaruhi petani dalam mengembangkan budidaya karet. Harga karet yang tinggi merupakan hal

\section{Idetifikasi Masalah}

Apakah harga, luas lahan dan produksi mempengaruhi partisipasi petani dalam mengembangkan budidaya karet di Kecamatan Karang Baru Kabupaten Aceh Tamiang.

\section{Tujuan Penelitian}

yang sangat diharapkan oleh petani karet. Untuk meningkatkan harga karet, petani karet harus meningkatkan mutu kualitas karet. Dengan meningkatnya harga karet, maka pendapatan petani juga meningkat.

Harga merupakan nilai barang yang ditentukan dengan uang atau jumlah uang yang merupakan alat tukar dalam membeli suatu barang yang dihitung dalam rupiah $/ \mathrm{kg}$. Semakin bagus suatu barang maka akan semakin mahal pula harga suatu barang dan semakin tidak bagusnya suatu barang maka akan semakin murah pula harga suatu barang tersebut.

Luas lahan merupakan salah satu faktor yang penting dalam mengembangkan budidaya karet, lahan karet yang luas akan menghasilkan produksi yang tinggi. Lahan sebagai media pertumbuhan karet luasya harus dijaga sehingga tidak terjadi ahli fungsi lahan karet menjadi lahan perkebunan kelapa sawit.

Luas lahan merupakan jumlah lahan yang dapat digunakan dalam berbagai kegiatan seperti kegiatan pertanian, industri, pemukiman, yang ada dalam suatu wilayah. Pentingnya peranan luas lahan harus sesuai dengan pemanfaatan akan kebutuhan lahan, pengunaan lahan tidak tepat akan mengakibatkan kerusakan lahan.

Produksi merupakan suatu kegiatan yang dikerjakan untuk menambah nilai guna suatu benda atau menciptakan benda baru sehingga lebih bermanfaat dalam memenuhi kebutuhan. Kegiatan menambah daya guna suatu benda tanpa mengubah bentuknya dinamakan produksi jasa sedangkan kegiatan menambah daya guna suatu benda dengan mengubah sifat dan bentuknya dinamakan produksi barang.

Untuk mengetahui pengaruh harga, luas lahan dan produksi terhadap partisipasi petani dalam mengembangkan budidaya karet di Kecamatan Karang Baru Kabupaten Aceh Tamiang.

\section{Hipotesis}

Harga, luas lahan dan produksi 
berpengaruh terhadap partisipasi petani dalam mengembangkan budidaya karet di Kecamatan Karang Baru Kabupaten Aceh Tamiang.

\section{METODOLOGI}

\section{PENELITIAN}

Lokasi, Objek, Ruang Lingkup, dan Waktu Penelitian.

Penelitian ini dilakukan di Kecamatan Karang Baru Kabupaten Aceh Tamiang dengan menggunakan "Metode Survey". Menurut M.Nazir (2005:271) Metode Survey adalah metode dimana hanya sebagian dari populasi saja yang diambil dan digunakan untuk menentukan sifat serta ciri yang dikehendaki dari populasi.

Objek penelitian ini adalah petani yang memiliki usahatani karet di Kecamatan Karang Baru Kabupaten Aceh Tamiang. Ruang lingkup penelitian ini terbatas pada harga, luas lahan dan produksi karet terhadap partisipasi petani di Kecamatan Karang Baru Kabupaten Aceh Tamiang,

\section{Populasi dan Sampel Penelitian}

Populasi dalam penelitian ini adalah semua petani karet yang terdapat di Kecamatan Karang Baru Kabupaten Aceh Tamiang yang terdiri dari 31 desa dimana Tabel II-1. Keadaan Jumlah Populasi dan Sampel Petani Karet di Kecamatan Karang Baru

\begin{tabular}{|l|l|c|c|}
\hline No & \multicolumn{1}{|c|}{ Desa Sampel } & $\begin{array}{c}\text { Populasi } \\
\text { (Orang) }\end{array}$ & $\begin{array}{c}\text { Sampel } \\
\text { (Orang) }\end{array}$ \\
\hline 1 & Menanggini & 40 & 16 \\
2 & Alur Selalas & 30 & 12 \\
3 & Alur Baung & 30 & 12 \\
\hline & Jumlah & 100 & 40 \\
\hline
\end{tabular}

Sumber : Data Primer, Tahun 2015 (diolah)

Tabel II-1 di atas memperlihatkan bahwa jumlah populasi petani karet di Kecamatan Karang Baru yaitu 100 orang yang terdiri dari Desa Menanggini sebanyak 40 orang, Desa Alur Selalas sebanyak 30 orang dan Desa Alur Baung sebanyak 30 orang. Sehingga diperoleh petani sampel sebanyak 40 orang yang terdiri dari 16 orang dari Desa Menanggini, 12 orang dari Desa Alur Selalas dan 12 orang hanya 21 desa yang terdapat usahatani karet. Penentuan desa sampel dilakukan secara sengaja (Purposive Sampling). Menurut Sugiyono (2008:122) "Purposive Sampling adalah teknik penentuan sampel dengan pertimbangan tertentu". Dari 21 desa yang ada di Kecamatan Karang baru desa sampel yang diambil adalah sebanyak $15 \%$ dari populasi. Desa-desa yang terpilih sebagai desa sampel yaitu Desa Menanggini, Desa Alur Selalas dan Desa Alur Baung dengan pertimbangan bahwa desa sampel yang dipilih memiliki luas lahan tertinggi dibandingkan desa yang lain.

Pengambilan petani sampel dilakukan dengan menggunakan metode Simple Random Sampling dengan teknik pengambilan secara acak, dimana semua populasi mempunyai kesempatan yang sama untuk menjadi sampel, kemudian diacak dengan cara mengambil sejumlah yang diinginkan. Menurut Sugiyono (2008:118) "Simple Random Sampling" adalah teknik penetuan sampel dari populasi diambil secara acak tanpa memperhatikan strata yang ada dalam populasi tersebut. Jumlah petani sampel yang diambil adalah sebanyak $40 \%$ dari populasi petani tiap-tiap desa sampel. Adapun jumlah populasi dan sampel petani karet dapat dilihat pada tabel berikut ini : dari Desa Alur Baung.

\section{Metode Pengumpulan Data}

Data yang diambil dan dikumpulkan dalam penelitian ini terdiri dari data primer dan data sekunder.

1. Data primer yaitu data yang diperoleh langsung dari lokasi penelitian. Teknik pengumpulan data yang dilakukan yaitu: Wawancara, 
Observasi dan Quisioner.

2. Data sekunder adalah sumber data yang diperoleh dari bukubuku bacaan, literatur, artikelartikel dan sumber-sumber lainnya

\section{Konsep Operasional Variabel}

Dalam penelitian ini dibutuhkan variabel sebagai berikut :

1. Partisipasi adalah partisipasi dapat berupa saran, jasa, ataupun dalam bentuk materi baik secara langsung maupun tidak langsung dalam suasana demokratis untuk mengembangkan budidaya karet di hitung dalam Skor.

2. Harga adalah sejumlah uang yang harus dikeluarkan oleh konsumen untuk mendapatkan produk atau jasa yang dibelinya guna memenuhi kebutuhan dan keinginanya. Harga dalam penelitian ini dihitung dalam rupiah/kg

3. Luas lahan merupakan faktor utama dalam mengembangkan usaha budidaya tanaman karet. Dalam penelitian ini luas lahan dihitung dengan satuan Hektar.

4. Produksi tanaman karet yang dihasilkan merupakan suatu rangkaian padat karya yang meliputi kegiatan penyadapan, pengumpulan lateks dan pembekuan lateks. Dalam penelitian ini karet box yang diteliti, produksi dihitung dengan $\mathrm{kg} / \mathrm{ha}$

5. Nilai untuk variabel partisipasi dalam penelitian ini dihitung dalam skor

\section{Metode Analisis dan Pengujian Hipotesis Analisis Data}

Data yang dikumpulkan di lapangan diolah dan ditabulasikan menurut kebutuhan analisis. Model yang digunakan dalam penelitian ini adalah dengan menggunakan Regresi Linier Berganda. Persamaan adalah sebagai berikut : $\mathrm{Y}$ $a_{0}+a_{1} X_{1}+a_{2} X_{2}+a_{3} X_{3}+e$ (Sudjana

$2005: 347)$

Keterangan :

$\mathrm{Y} \quad=$ Partisipasi petani (Skor) yang didapat diperpustakaan, lembaga atau instansi pemerintah yang terkait dengan kebutuhan penelitian.

dengan menggunakan skala Likert. Skala Likert yaitu " Untuk mengukur sikap, pendapat, dan persepsi seseorang atau sekelompok orang tentang fenomena sosial (Sugiyono, 2008:133). Variabel yang dinilai untuk menentukan tingkat partisipasi petani dalam mengembangkan budidaya karet yang dinilai dalam penelitian ini meliputi:

a. Sistem penanaman karet

b. Pupuk yang digunakan

c. Teknik dan frekuensi penyadapan yang dilakukan

d. Cara pengendalian hama dan penyakit yang dilakukan pada usahatani karet

e. Jenis klon karet yang Bapak/lbu gunakan pada usahatani karet

f. Bahan yang digunakan untuk pembekuan lateks dalam pasca panen

Untuk menentukan nilai skor dari masingmasing variabel digunakan ketentuan sebagai berikut:

1) Sesuai Anjuran diberi skor 3

2) Kurang Sesuai Anjuran diberi skor 2

3) Tidak Sesuai Anjuran (TS) diberi skor 1

$$
\begin{array}{ll}
\text { ao } & =\text { Konstanta } \\
\mathrm{X}_{1} & =\text { Harga }(\mathrm{Rp} / \mathrm{Kg}) \\
\mathrm{X}_{2} & =\text { Luas lahan }(\mathrm{Ha}) \\
\mathrm{X}_{3} & =\text { Produksi }(\mathrm{Kg} / \mathrm{Ha})
\end{array}
$$

a1, a2 dan a3 = Parameter yang dicari

e $=$ Standar error

Untuk melihat perbandingan antara $Y$ yang dijelaskan oleh variabel $\mathrm{X}_{1}, \mathrm{X}_{2}$ dan $\mathrm{X}_{3}$ digunakan koefisiensi determinasi. Sudjana, (2005:383) menjelaskan "Koefisiensi determinasi $\left(R^{2}\right)$ adalah proporsi keragaman atau variansi total nilai peubah $Y$ yang dapat 
dijelaskan oleh nilai peubah $\mathrm{X}$ melalui hubungan linier".

Untuk menguji pengaruh secara serempak variabel Independen $\left(X_{1}, X_{2}\right.$ dan $\left.\mathrm{X}_{3}\right)$ terhadap variabel dependen $(\mathrm{Y})$, digunakan Uji F. Sudjana (2005:385) menjelaskan "Uji $\mathrm{F}$ adalah metode pengujian yang dilakukan untuk mengetahui pengaruh variabel bebas secara bersama-sama terhadap variabel terikat".

Untuk mengetahui pengaruh masingmasing variabel atau secara parsial digunakan Uji t untuk pengujian. Sudjana, (2005:373) menjelaskan " $U j i \mathrm{t}$ adalah metode pengujian yang dilakukan untuk mengetahui pengaruh variabel bebas secara individual terhadap variabel terikat".

\section{HASIL DAN PEMBAHASAN \\ Karakteristik Petani}

Rata-rata umur petani sampel usahatani karet di Kecamatan Karang Baru adalah 41 tahun, berdasarkan ratarata umur usahatani karet petani sampel menunjukkan bahwa umur tersebut masih produktif dalam berusahatani. Pada pendidikan usahatani karet petani sampel rata-rata 8 tahun. Ini berarti umur usahatani karet di Kecamatan Karang Baru rata-rata Sekolah Lanjutan Tingkat Pertama (SLTP), dan rata-rata pengalaman petani sampel dalam usahatani karet sebesar 14 tahun.

dilihat pada tabel V-2 berikut:

Untuk mengetahui rata-rata harga karet di Kecamatan Karang Baru dapat Tabel V-2. Rata-rata Harga Harga Karet di Kecamatan Karang Baru

\begin{tabular}{|c|l|c|}
\hline No & \multicolumn{1}{|c|}{ Desa Sampel } & Harga $(\mathrm{Rp} / \mathrm{Kg})$ \\
\hline 1 & Menanggini & 6.375 \\
2 & Alur Selalas & 6.300 \\
3 & Alur Baung & 6.200 \\
\hline & Rata-rata & 6.292 \\
\hline
\end{tabular}

Sumber : Data primer diolah

Tabel V.-2 di atas dapat dilihat bahwa rata-rata harga karet di desa sampel di Kecamatan Karang Baru sebesar Rp.6.292/kg dengan rincian harga karet di Desa Menanggini sebesar Rp.6.375/kg, di Desa Alur Selalas sebesar Rp.6.300/kg, dan

\section{Luas Lahan}

Untuk lebih jelas mengenai luas garapan pada usahatani karet di Kecamatan Karang Baru dapat dilihat pada tabel V-3 berikut :

di Desa Alur Baung sebesar Rp.6.200/kg.

Tabel V-3. Rata-rata Luas Lahan Usahatani Karet di Kecamatan Karang Baru,

\begin{tabular}{|c|l|c|}
\hline No & \multicolumn{1}{|c|}{ Desa Sampel } & Luas Lahan (Ha) \\
\hline 1 & Menanggini & 1,22 \\
2 & Alur Selalas & 1,46 \\
3 & Alur Baung & 1,38 \\
\hline & Rata-rata & 1,35 \\
\hline
\end{tabular}

Sumber : Data primer diolah

Tabel V-3 diatas dapat dilihat bahwa ratarata luas lahan karet di desa sampel di Kecamatan Karang Baru sebesar 1,35 hektar dengan rincian luas lahan karet di Desa Menanggini sebesar 1,22 hektar, di
Desa Alur Selalas sebesar 1,46 hektar, dan di Desa Alur Baung sebesar 1,38 hektar.

Produksi Karet 
Berdasarkan hasil penelitian produksi karet pada saat penelitian adalah $80 \mathrm{~kg} / \mathrm{ha} / \mathrm{minggu}$. Untuk lebih jelas tentang besarnya produksi karet

Tabel V-4. $\quad$ Rata-rata Produksi Per Minggu pada Usahatani Karet Berdasarkan Desa Sampel di Kecamatan Karang Baru

\begin{tabular}{|c|l|c|}
\hline No & \multicolumn{1}{|c|}{ Desa Sampel } & Produksi (kg/minggu) \\
\hline 1 & Menanggini & 103 \\
2 & Alur Selalas & 108 \\
3 & Alur Baung & 103 \\
\hline & Rata-rata & 105 \\
\hline
\end{tabular}

Sumber : Data primer diolah

Tabel V-4 diatas dapat dilihat bahwa rata-rata produksi karet di desa sampel di Kecamatan Karang Baru sebesar 105 hektar per minggu dengan rincian produksi karet di Desa Menanggini sebesar 103 $\mathrm{kg} / \mathrm{ha} / \mathrm{minggu}$, di Desa Alur Selalas sebesar $108 \mathrm{~kg} / \mathrm{ha} / \mathrm{minggu}$, dan di Desa Alur Baung

sebesar $103 \mathrm{~kg} / \mathrm{ha} / \mathrm{minggu}$.

\section{Partisipasi Petani}

Untuk lebih jelasnya jumlah skor dari tingkat partisipasi petani karet di Kecamatan Karang Baru dilihat pada tabel V5 berikut :

Tabel V-5. Rata-rata Jumlah Skor Tingkat Partisipasi Petani Karet di Kecamatan Karang Baru

\begin{tabular}{|c|l|c|}
\hline No & \multicolumn{1}{|c|}{ Desa Sampel } & Rata-rata Partisipasi Petani (Skor) \\
\hline 1 & Menanggini & 2,00 \\
2 & Alur Selalas & 2,00 \\
3 & Alur Baung & 3,00 \\
\hline & Rata-Rata & 2,33 \\
\hline
\end{tabular}

Sumber : Data primer diolah

Tabel V-5 diatas menunjukkan bahwa rata-rata tingkat partisipasi petani karet di Kecamatan Karang Baru yaitu sebesar 2 skor. Secara rinci rata-rata tingkat partisipasi di Desa Menanggini 2 skor, Desa Alur Selalas 2 skor, dan Desa Alur Baung 3 skor. Untuk melihat rincian tingkat partisipasi petani karet berdasarkan jenis

kegiatan di Kecamatan Karang Baru dapat dilihat pada uraian berikut:

\section{Sistem penanaman karet}

Hasil perhitungan skor sistem penanaman karet dapat dilihat pada tabel V-6 berikut:

Tabel V-6. Rata-rata Skor Sistem Penanaman Usahatani Karet Berdasarkan Desa Sampel di Kecamatan Karang Baru

\begin{tabular}{|c|l|c|}
\hline No & \multicolumn{1}{|c|}{ Desa Sampel } & Sistem Penanaman Karet (Skor) \\
\hline 1 & Menanggini & 2 \\
2 & Alur Selalas & 3 \\
3 & Alur Baung & 2 \\
\hline & Rata-rata & 2 \\
\hline
\end{tabular}

Sumber : Data primer diolah

Tabel V-6 dapat dilihat bahwa rata-rata tingkat partisipasi petani usahatani karet di Kecamatan Karang Baru berdasarkan sistem penanaman karet sebagian besar dilakukan sistem penanaman karet yaitu sistem tumpang sari dengan jarak tanam $8 \times 4$ (skor 2) artinya petani dalam melakukan sistem penanaman karet 
kurang sesuai anjuran.

Pemupukan

Hasil perhitungan skor pemupukan

Tabel V-7. Rata-rata Skor Pemupukan Usahatani Karet Berdasarkan Desa Sampel di Kecamatan Karang Baru

\begin{tabular}{|c|l|c|}
\hline No & \multicolumn{1}{|c|}{ Desa Sampel } & Pemupukan (Skor) \\
\hline 1 & Menanggini & 2 \\
2 & Alur Selalas & 2 \\
3 & Alur Baung & 2 \\
\hline & Rata-rata & 2 \\
\hline
\end{tabular}

Sumber : Data primer diolah

Tabel V-7 dapat dilihat bahwa rata-

rata tingkat partisipasi petani usahatani

karet di Kecamatan Karang Baru

berdasarkan jenis kegiatan pemupukan

usahatani karet sebagian besar

penggunaan pupuk meliputi pupuk Urea

dan pupuk TSP (skor 2) artinya petani pada usahtani karet dapat dilihat pada tabel V-7 berikut: dalam melakukan sistem pemupukan karet kurang sesuai anjuran.

\section{Penyadapan karet}

Hasil perhitungan skor sistem penyadapan dapat dilihat pada tabel V-8 berikut:

Tabel V-8. Rata-rata Skor Sistem Penyadapan Usahatani Karet Berdasarkan Desa Sampel di Kecamatan Karang Baru

\begin{tabular}{|c|l|c|}
\hline No & \multicolumn{1}{|c|}{ Desa Sampel } & Penyadapan (Skor) \\
\hline 1 & Menanggini & 3 \\
2 & Alur Selalas & 3 \\
3 & Alur Baung & 3 \\
\hline & Rata-rata & 3 \\
\hline
\end{tabular}

Sumber : Data primer diolah

Tabel V-8 dapat dilihat bahwa rata-

rata tingkat partisipasi petani usahatani

karet di Kecamatan Karang Baru berdasarkan penyadapan karet sebagian besar dilakukan penyadapan dua'bidang sadap secara bergantian dengan pohon yang disadap dua hari sekali (skor 3 ) artinya

Tabel V-9. Rata-rata Skor Pemeliharaan Usahatani Karet Berdasarkan Desa Sampel di Kecamatan Karang Baru

\begin{tabular}{|c|l|c|}
\hline No & \multicolumn{1}{|c|}{ Desa Sampel } & Pemeliharaan (Skor) \\
\hline 1 & Menanggini & 3 \\
2 & Alur Selalas & 3 \\
3 & Alur Baung & 3 \\
\hline
\end{tabular}

Sumber : Data primer diolah

Tabel V-9 dapat dilihat bahwa rata-

rata tingkat partisipasi petani usahatani

karet di Kecamatan Karang Baru berdasarkan tingkat pemeliharaan tanaman karet sebagian besar dilakukan

petani dalam melakukan penyadapan karet sesuai anjuran.

\section{Pemeliharaan}

Hasil perhitungan skor tingkat pemeliharaan dapat dilihat pada tabel V-9 sebagai berikut: 
Jenis Klon

Hasil perhitungan skor tingkat jenis

Tabel V-10. Rata-rata Skor Tingkat Jenis Klon Usahatani Karet Berdasarkan Desa Sampel di Kecamatan Karang Baru

\begin{tabular}{|l|l|c|}
\hline No & \multicolumn{1}{|c|}{ Desa Sampel } & Jenis Klon (Skor) \\
\hline 1 & Menanggini & 2 \\
2 & Alur Selalas & 2 \\
3 & Alur Baung & 2 \\
\hline & Rata-rata & 2 \\
\hline
\end{tabular}

Sumber : Data primer diolah

Tabel V-10 dapat dilihat bahwa rata-

rata tingkat partisipasi petani usahatani

karet di Kecamatan Karang Baru berdasarkan penggunaan jenis klon tanaman karet sebagian besar jenis klon BPM (skor 2) artinya petani dalam menggunakan klon karet belum sesuai

Tabel V-11. Rata-rata Skor Bahan Pembekuan Lateks Usahatani Karet Berdasarkan Desa Sampel di Kecamatan Karang Baru

\begin{tabular}{|c|l|c|}
\hline No & \multicolumn{1}{|c|}{ Desa Sampel } & Bahan Pembekuan Lateks (Skor) \\
\hline 1 & Menanggini & 3 \\
2 & Alur Selalas & 3 \\
3 & Alur Baung & 3 \\
\hline & Rata-rata & 3 \\
\hline
\end{tabular}

Sumber : Data primer diolah

Tabel V-11 dapat dilihat bahwa ratarata tingkat partisipasi petani usahatani karet di Kecamatan Karang Baru berdasarkan penggunaan bahan pembekuan lateks tanaman karet sebagian besar menggunakan asam format (asam semut) (skor 3) artinya petani dalam bahan pembekuan lateks karet sesuai anjuran.

\section{Pengaruh Harga, Luas Lahan, dan Produksi Terhadap Partisipasi

Partisipasi petani dalam
mengembangkan budidaya karet di daerah penelitian dipengaruhi oleh harga, luas lahan dan produksi, sedangkan faktor-faktor lain dianggap tetap. Hasil analisis diperoleh Persamaan Regresi Linear Berganda sebagai berikut :

$Y=1,99+0,08 X_{1}+$

$0,97 X_{2}-1,17 X_{3}$.

Dari persamaan di atas dapat disimpulkan bahwa:

a. Setiap penambahan harga karet anjuran.

\section{Bahan Pembekuan Lateks}

Hasil perhitungan skor bahan pembekuan lateks klon dapat dilihat pada tabel V-11 sebagai berikut: Rp. $\quad 1.000$ maka partisipasi usahatani karet bertambah sebesar 80 skor. Hal ini terjadi karena semakin naik harga, maka partisipasi petani karet dalam berusahatani semakin bertambah.

b. Setiap penambahan 1 hektar lahan tanaman karet maka partisipasi usahatani karet bertambah sebesar 0,97 skor. Hal ini terjadi karena semakin luas lahan tanaman karet, maka partisipasi petani karet dalam berusahatani semakin bertambah.

c. Setiap penambahan $1 \mathrm{~kg}$ karet maka partisipasi usahatani karet bertambah sebesar 1,17 skor. Hal ini terjadi karena semakin tinggi produksi karet, maka partisipasi petani karet dalam berusahatani bertambah.

Koefisien Determinasi $\left(\mathbf{R}^{\mathbf{2}}\right)$

Hasil analisis koefisien determinasi 
$\left(R^{2}\right)$ dihasilkan nilai $R^{2}=0,51$ atau $51 \%$.

Ini berarti partisipasi petani dalam berusahatani karet $(Y)$ dipengaruhi oleh harga $\left(X_{1}\right)$, luas lahan $\left(X_{2}\right)$, dan produksi $\left(X_{3}\right)$ sebesar $51 \%$ dan sisanya sebesar $49 \%$ lagi dipengaruhi oleh faktor-faktor lain diluar Tabel V. 12. Hasil uji secara serempak (uji F)

\begin{tabular}{|l|c|c|c|}
\hline No & F hitung & \multicolumn{2}{|c|}{ F tabel } \\
\hline & & 0.05 & 0.01 \\
\hline 1 & 12,63 & 2,86 & 4,36 \\
\hline
\end{tabular}

Sumber: Data primer diolah

Hasil pengujian secara serempak diperoleh Fhitung $=12,63>$ Ftabel $=$ 2,86 pada tingkat kepercayaan 95\% (回 = $0,05)$ dan juga Fhitung $=12,63>$ Ftabel $=4,36$ pada tingkat kepercayaan 99\% (? = 0,01 ), dapat diambil kesimpulan bahwa secara serempak variabel tingkat harga, luas lahan, dan produksi memberikan pengaruh yang sangat nyata terhadap Tabel V. 13. Hasil Uji Secara Parsial (uji t)

\begin{tabular}{|l|l|l|l|l|}
\hline No & Variabel Bebas & Thitung & $T_{\text {tabel } 0,05}$ & $T_{\text {tabel } 0,01}$ \\
\hline 1 & Harga & 11,76 & 1,691 & 2,440 \\
2 & Luas Lahan & 22,26 & 1,691 & 2,440 \\
3 & Produksi & $-54,72$ & 1,691 & 2,440 \\
\hline
\end{tabular}

Sumber: Data primer diolah

Hasil pengujian secara parsial pada variabel harga $\left(X_{1}\right)$ tingkat kepercayaan $95 \%$ (? = 0,05) dapat dilihat bahwa $\mathrm{t}_{1}$ cari $=11,76$ dan $\mathrm{t}_{2}$ cari $=22,26>\mathrm{t}$ tabel $=1,691 \mathrm{dan} \mathrm{t}$ tabel $=2,440$ pada tingkat kepercayaan $99 \%$ (? = 0,01), ini berarti harga dan luas lahan berpengaruh sangat nyata terhadap partisipasi petani usahatani karet di daerah penelitian. Hasil pengujian secara parsial pada variabel produksi ( $\left.\mathrm{X}_{3}\right)$ tingkat kepercayaan $95 \%(\alpha=0,05)$ dapat dilihat bahwa t3 cari $=1,98<\mathrm{t}$ tabel 1,691 dan pada tingkat kepercayaan $99 \% \quad(\alpha=0,01)$ bahwa $\mathrm{t} 3$ cari $=-54,72<\mathrm{t}$ tabel $=2,440$, ini berarti tingkat produksi tidak berpengaruh nyata terhadap partisipasi petani usahatani karet di penelitian.

\section{KESIMPULAN}

DAN SARAN variabel penelitian ini.

Uji F

Hasil perhitungan dapat dilihat pada tabel V12 berikut: partisipasi petani karet. Hal ini disebabkan bahwa harga karet dipasaran berubah-rubah, lahan yang kurang luas, produksi yang berkurang maka tingkat partisipasi petani dalam usahatani karet.

\section{Uji t}

Hasil perhitungan dapat dilihat pada tabel V13 berikut:

\section{Kesimpulan}

1. Hasil analisis regresi linear berganda diperoleh persamaan yaitu sebagai berikut: $Y=1,99+0,08 X_{1}+0,97 X_{2}$ $-1,17 X_{3}$

2. Dari koefisien determinasi menunjukkan bahwa besar koefisien determinasi $\left(R^{2}\right)$ dihasilkan nilai $R^{2}=0,51$ atau $51 \%$.

3. Hasil pengujian secara serempak diperoleh Fhitung $=12,63>$ Ftabel $=2,86$ pada tingkat kepercayaan $95 \%($ (a $=0,05)$ dan juga Fhitung $=12,63>$ Ftabel $=4,36$ pada tingkat kepercayaan $99 \%$ (? $=0,01)$, secara serempak variabel faktor tingkat harga, luas lahan, dan produksi berpengaruh sangat nyata terhadap partisipasi petani karet. 
4. Hasil pengujian secara parsial pada variabel harga $\left(X_{1}\right)$ dan variabel luas lahan $\left(X_{2}\right)$ berpengaruh sangat nyata terhadap partisipasi. Sedangkan variabel produksi $\left(\mathrm{X}_{3}\right)$ hanya berpengaruh nyata.

Saran

1. Diharapkan adanya program dari pemerintah dalam mengembangkan produk pengolahan industri yang berbahan baku dari karet, agar hasil produksi dapat berkembang menjadi produk berdaya jual tinggi.

2. Para petani karet dalam berusahatani hendaknya mengetahui secara baik dan jelas tentang harga, luas lahan, dan produksi yang dihasilkan dalam berusahatani karet.

3. Selanjutnya kepada peneliti-peneliti agar menambah variabel-variabel lain yang lebih konkrit yang hubungannya dengan partisipasi oleh petani karet di Kecamatan Karang Baru.

\section{DAFTAR PUSTAKA}

Anonimous, 2007. Budidaya dan Pengolahan Karet. Penebar Swadaya, Jakarta

Anonimous, 2008. Panduan Lengkap Karet. Penerbit Penebar Swadaya. Jakarta

Anonimous. 2014. Luas Lahan Produksi dan Produktivitas Usahatani Karet. BPS Aceh Tamiang

Anonimous. 2014. Potensi Wilayah. Kecamatan Karang Baru Kabupaten Aceh Tamiang. BPP Kecamatan Karang Baru

Anonimous. 2014. Aceh Tamaing dalam Angka 2014. Badan Pusat Statitistik Aceh Tamiang. Kabupaten Aceh Tamiang.

Anwar, 2010. Faktor yang Mempengaruhi Lahan Karet. agribisnis.fp.uns.ac.id/wpcontent/uploads/2015/01/Jurnal.pdf. Diakses Pada Tanggal 15 Maret 2015

Assauri, Sofyan, 2000. Manajemen Produksi. FE-UI, Jakarta

Bastari, 2008. The Production of Indonesian Natural Rubber and Its Outlook. Slide Presentation of Gapkindo in The
Fifth Shanghai Derivetives Market Forum.

Kiki, Dee. 2014. Faktor-Faktor Yang Mempengaruhi Harga Karet. http://koranbekas90. com / 2014/11/. Diakses Pada Tanggal 15 Maret 2015

Mubyarto, 1996.

Manajemen

Keuangan.

Salemba

Empat. Jakarta.

Nazir, Moh, 2005.

Metode

Penelitian.

Ghalia

Indonesia,

Jakarta..

Rio, Ardi. 2009. Budidaya karet. https:rioardi.wordpress.com/2009/03 /25/karet- hevea-brasiliensis-budidaya-dan-penanamanya. Diakses Pada Tanggal 15 Maret 2015

Shinta, A. 2011. Ilmu Usahatani. Penerbit Universitas Brawijaya Press (UB Press) Anggota IKAPI. Malang.

Sudjana, 2005. Teknik Analisa Regresi dan Korelasi. Tarsito. Bandung.

Suhartono, 2011. Partisipasi Mayarakat Dalam Membangun Desa, Artikel Buletin 24 Pembangunan. Jakarta.

Sugiyah, 2010. Partisipas, eprints.uny.ac.id, Diakses Pada Tanggal 05 Mei 2015

Sugiyono, 2008. Respon Konsumen, Alfabeta. Bandung

Tilaar, H.A.R. 2009. Partisipasi, Intermedia, Jakarta. 